\title{
Can the integration of a PLE in an e-portfolio platform improve generic competences?
}

\author{
Cristina Galván-Fernández ${ }^{1 *}$ @], María José Rubio-Hurtado²®, Francesc Martínez- \\ $\mathrm{Olmo}^{3}$ (), José Luis Rodríguez-IIlera ${ }^{4}$ (i) \\ 'Department Theory and History of Education, University of Barcelona, Spain \{cgalvan@ub.edu\} \\ 2Department Methods of Research and Diagnosis in Education, University of Barcelona, Spain \\ \{mjrubio@ub.edu\} \\ ${ }^{3}$ Department Methods of Research and Diagnosis in Education, University of Barcelona, Spain \\ \{fmartinezo@ub.edu\} \\ 4Department Theory and History of Education, University of Barcelona, Spain \{jlrodriguez@ub.edu\} \\ Received on 20 January 2017; revised on 7 February 2017; accepted on 23 Febreruary 2017; published on 15 July 2017
}

DOI: $10.7821 /$ naer.2017.7.230

(cc) BY-NC-ND

\begin{abstract}
The study analyzes the improvement in generic competences through e-portfolio/PLE platform and didactic planning. The new version of the platform, Digital Folder, contains utilities for students and teachers and some PLE components that help the learning process through e-portfolios. Didactic planning is compared for students from the University of Vic and the University of Barcelona, with a total of 61 participants. A questionnaire has been applied for measuring the use of functions and how much these functions aid in the improvement of the generic competences (reflection, planning and selection of information). The results confirm that the most helpful functions for students are: the Schedule, the Academic tasks, the Teacher's portfolio and Dialogue with the teacher. However, the implication of these functions in the improvement of the competences depends on didactic planning overall for reflection on learning.
\end{abstract}

KEYWORDS: EPORTFOLIO, PLE, GENERIC COMPETENCES, HIGHER EDUCATION

\section{INTRODUCTION}

The last decade has seen a notable increase in research into e-portfolios, platform design and systems, based on Web 2.0, along with the teaching strategies employed. However, there are far fewer publications devoted to research into improvements in the development of competences.

In the university environment, e-portfolios tend to be used with an evidence-based learning approach, whereby a set of documents or evidence of learning are grouped together with reflection on learning, normally of a metacognitive nature (Barberà, 2008; Barrett, 2003; Cambridge, 2010; Zubizarreta, 2009). The evidence is increasingly multimedia-based and interconnected through hypertext links.

E-portfolios can also be seen as a personal learning environment. A personal environment helps the student to learn with

*To whom correspondence should be addressed:

Dept. Teoria e Historia de la Educación, Campus Mundet

Pg. Vall d'Hebrón, 171; 08035 Barcelona (Spain) others, to control learning resources, to manage the participation of resources and to manage the integration of resources in learning. In this way, the evidence of learning can be strengthened, as can the process of creating the e-portfolio.

Johnson and Liber (2008) propose a model of personal organisation in environments that can be described as PLEs (personal learning environments). This model (Beer's Viable System Model or VSM) proposes connecting learning activities to higher-level cognitive functions. Examples include coordinating learning activities with the institution, negotiating the resources required in each activity and managing the complexity of the learning activities. In order for students to find the platform meaningful, they must focus on the so-called self-delivery functions of learning management, such as scheduling, self-assessment and messaging tools, etc. When students are driven by their own interest and motivation to manage these tools in order to optimise the learning process, it is considered that these functions form part of their self-development, however students need guidance and support for engaging with new digital tools (Kuhn, 2017). The reflective process of the learning itself serves to strike a balance between these self-delivery and self-development characteristics. In line with the self-development aspect of PLEs, Cambridge (2010) introduces the concept of the self-networked and the self-symphonic to describe students who show evidence of learning through the e-portfolio. The self-networked refers to the connections made with other settings (social networks, teaching staff, fellow students, external information, etc.) by the student through the functions of the e-portfolio system. Meanwhile, the construction of the self-symphonic is the process whereby students integrate learning, interests and modes of representation in such a way as to benefit their self-development. As such, we can see how e-portfolios and other personal learning environments may foster students' development when reflection on the learning process takes place and, therefore, from the perspective of evidence-based learning.

Within the framework of e-portfolios, several authors link the process of creating the portfolio to the development of cross-cutting and metacognitive competences (Logar, Peterson, \& Römmer-Nossek, 2007; Meyer, Abrami, Wade, Aslan, \& Deault, 2010; Plaisir, Hachey, \& Theilheimer, 2011). Cross-cut- 
ting competences are those which require a higher level of mental complexity, foster the development of levels of intellectual thought and the development of attitudes and values, involve an active and reflective approach, and are multifunctional, among other aspects (Villa \& Poblete, 2007). Meanwhile, metacognitive competences are those associated with self-reflection and self-assessment.

Reflecting on the learning process involves deep learning, finding meaning in learning, connecting and evaluating the implications of actions in the learning process and knowing the variations in points of view as actions are being carried out, among other factors (Hole \& McEntee, 1999; Riedinger, 2006). At the same time, according to Pintrich (2004), this competency involves four stages, which include the planning of learning (goal setting and activation of prior knowledge), the control of motivation and effort, the selection and adaptation of strategies, and reflection on the progress of the task.

The planning of the learning process is a combination of the planning of a task and orientation to learning (Villa \& Poblete, 2007). In this respect, we see planning as an element of appropriation and personalisation of the assessment system in order to be able to specify objectives, timings, methods and strategies, as well as to carry out the self-assessment of the aforementioned objectives (Justicia, 1996; Torrano \& González, 2004).

Meanwhile, by producing e-portfolios, students select information in order to draw up learning evidence, as well as selecting the documents that constitute evidence of learning. Information behaviour can be understood on different levels of the person-information interaction process, based on the description of information-seeking processes and that of the specific techniques for extracting information (Wilson, 1999). At the same time, the process of extracting information entails the selection of information, which means that the person defines the topics to be investigated and the procedures to be used in this investigation. The selection process involves evaluation strategies that make it possible to define the information extraction procedures.

\subsection{Digital Folder (Carpeta Digital): an e-portfolio/ PLE system}

Digital Folder (http://app.carpetadigital.net) is a platform created to generate e-portfolios in the university setting. This involves the participation of three agents: the student, the teacher and an administrator, each of whom has specific functions, namely the creation of the portfolio, the assessment of the portfolio, and the distribution of portfolios and users, respectively. The Digital Folder platform has certain assumptions regarding the educational relationship, such as (Rodríguez-Illera, Galván, Martínez-Olmo, 2013):

- Students continuously create the e-portfolio while teachers continuously monitor the learning.

- Students show evidence of the learning, which means that they may incorporate learning from other contexts (gained over the course of their lives) both in their narrative and in the digital and hypertextual presentation of the e-portfolio.

- Students share their e-portfolios with other interested parties, both while studying the subject and following its completion, in order to provide evidence of their competences.

A decade after it was launched, the Digital Folder platform continues to adapt to the pedagogical needs of students and teachers, as well as to the developments made in respect of applications. As regards the use of e-portfolios to show evidence of learning, the platform has incorporated components typically associated with a PLE (Castañeda \& Adell, 2013; Rodríguez-Illera, Rubio, Galván, \& Barberà, 2014; Siemens, 2007; Torres-Kompen, Buchem, \& Attwell, 2011). These components can be placed into four categories, related both to self-delivery functions, as explained above, and to self-development functions: 1) Applications that enable students to configure their own space (incorporate social networks, personal schedules, etc.); 2) Producing documents using the information of the applications themselves and that of the academic tasks assigned by the teacher, complementing the documents that could already be created and re-edited previously; 3) Sharing information (with options for comments and privacy) with users and non-users of the platform; 4) Improvement of the visual display of the set of subjects and of the relevant information, in order to help students with planning, providing a sort of "control centre". Some authors have analysed the appropriation of these kinds of tools as the visitors and residents concept for knowing how much self-development students are able to acieve (Kühn, 2017).

A recent overview of all the factors that affect PLE's student construction with personal, academic and professional perspectives is published by Castañeda, Dabbagh and Torres-Kompen (2017). The introduction of this issue shows how metacognition, approaches to technology, digital skills, guidance and support by teachers are related and engage the "spirit of PLE": sharing, collaboration and creating together; processes of the 2.0 world.

The overall objective of the study is to discover students' perceptions of the effect of an e-portfolio system, with an integrated PLE, on the development of cross-cutting competences. The specific objectives were:

- To find out whether the students perceive that their competences of planning, reflection and information selection are developed to a greater extent after using the e-portfolio.

- To find out the students' perception of the degree to which each function of the e-portfolio helps in the development of the three competences.

- To verify the possible influence of related variables in the perception of the development of competences, such as: a) the students' study habits, b) attitude towards reflection, c) the teacher's role in raising awareness about the use of the e-portfolio, d) the type of subject, and e) the students' performance.

\section{METHODS}

A questionnaire method was adopted, for which purpose three five-level Likert-type scales were designed from the perspective of the processes of self-regulated learning (Pintrich, 2004; Rosario, Núñez, \& González-Pineda, 2006; Wolters, 2003; Zimmerman, 2002), geared towards discovering the development of the following competences: Planning, Information selection and Reflection. For each item of the scales the students have to indicate whether they have developed the competences: 1) to a much lesser extent than before the use of the e-portfolio; 2) to a lesser extent than before the use of the e-portfolio; 3 ) to the same extent as before the use of the e-portfolio; 4) to a greater extent than before the use of the e-portfolio; 5) to a much greater extent than before the use of the e-portfolio. This type of scale has also been used in other studies (Geyer \& Daly, 1998; Littrell, Malia, \& 
Vanderwood, 1995), where a comparison was made of students' perception before and after an educational intervention.

The reliability of the scales measured by means of Cronbach's Alpha internal consistency index produced the following results (Table 1): 0.74 on the Reflection scale, 0.84 on the Information selection scale and 0.65 on the Planning scale. These values are considered acceptable for the purpose of this research (Nunnally \& Bernstein, 1995).

Table 1. Reliability of the scales

\begin{tabular}{lcl}
\hline \multicolumn{1}{c}{ Scale } & \multicolumn{1}{c}{ Alpha } & $\begin{array}{c}\text { Alpha if item was } \\
\text { deleted }\end{array}$ \\
\hline Planning & 0.65 (10 elements) & $\begin{array}{l}0.66 \text { if item } 10 \text { was } \\
\text { deleted (I plan sub- } \\
\text { jects well) }\end{array}$ \\
\hline Reflection & 0.74 (10 elements) & $\begin{array}{l}0.82 \text { if item } 9 \text { was } \\
\text { deleted (I am aware } \\
\text { of the usefulness of } \\
\text { reflection })\end{array}$ \\
\hline $\begin{array}{l}\text { Selection of the } \\
\text { information }\end{array}$ & $0.84(10$ elements) & \\
\hline
\end{tabular}

A factorial analysis was carried out in order to identify the structure of the constructs (Main Components with Varimax Rotation) for each of the scales (once the aforementioned items were eliminated). The Bartlett test confirmed that the factorial analysis was appropriate in the three scales $(\mathrm{p}=0.0000)$.

All the items had a loading of over 0.40 in the relevant factor and a loading of less than 0.30 in the non-relevant ones. The Planning and Information Selection scales show a structure of three factors, while the Reflection scale has a bidimensional structure. In all three cases the explained variance with the said factors exceeds $60 \%$ (Table 2 ).

Table 2. Factorial analysis of the scales

\begin{tabular}{|c|c|}
\hline $\begin{array}{c}\text { Planning (Explained variance } \\
66 \%)\end{array}$ & Saturation \\
\hline \multicolumn{2}{|l|}{ Factor 1} \\
\hline $\begin{array}{l}\text { I am concerned to know how } \\
\text { each of the studied topics will } \\
\text { help me in my future career }\end{array}$ & .85 \\
\hline $\begin{array}{l}\text { I draw up personal goals geared } \\
\text { toward completing courses and } \\
\text { other activities in order to achieve } \\
\text { certain competencies }\end{array}$ & .76 \\
\hline \multicolumn{2}{|l|}{ Factor 2} \\
\hline $\begin{array}{l}\text { I hand in activities by the indica- } \\
\text { ted due date }\end{array}$ & .65 \\
\hline I plan subjects well & .81 \\
\hline $\begin{array}{l}\text { I know how to manage my study } \\
\text { time }\end{array}$ & .62 \\
\hline $\begin{array}{l}\text { I keep the teaching programme in } \\
\text { mind throughout the subject }\end{array}$ & .62 \\
\hline $\begin{array}{l}\text { I plan in order to work out how to } \\
\text { achieve the competencies I need } \\
\text { for the subject }\end{array}$ & .49 \\
\hline \multicolumn{2}{|l|}{ Factor 3} \\
\hline $\begin{array}{l}\text { I make lists of what I need to } \\
\text { have or know in order to carry out } \\
\text { the activities }\end{array}$ & .87 \\
\hline
\end{tabular}

\begin{tabular}{ll}
\hline $\begin{array}{l}\text { I plan in a diary the dates for } \\
\text { carrying out the activities of the } \\
\text { subject }\end{array}$ \\
\hline Reflection (Explained variance 62\%) \\
\hline Factor $\mathbf{1}$ \\
\hline $\begin{array}{l}\text { My reflection is of a constructive } \\
\text { nature }\end{array}$ \\
\hline $\begin{array}{l}\text { My reflection is of a self-critical } \\
\text { nature }\end{array}$ \\
\hline I take the time necessary to reflect & .57 \\
\hline $\begin{array}{l}\text { I am aware of the usefulness of } \\
\text { reflection }\end{array}$ & .61 \\
\hline $\begin{array}{l}\text { I reflect even when not asked to } \\
\text { do so by the teacher }\end{array}$ & .45 \\
\hline Factor $\mathbf{2}$ \\
\hline $\begin{array}{l}\text { I reflect on the goals to be rea- } \\
\text { ched in order to know what I need } \\
\text { to achieve them }\end{array}$ \\
\hline $\begin{array}{l}\text { I reflect on my learning successes } \\
\text { and errors }\end{array}$ \\
\hline $\begin{array}{l}\text { I reflect on the strategies that may } \\
\text { help me improve learning }\end{array}$ \\
\hline $\begin{array}{l}\text { I reflect on the competencies that } \\
\text { help me to achieve the learning } \\
\text { activities }\end{array}$ \\
\hline
\end{tabular}

\begin{tabular}{l}
\hline Information selection (Explained variance 65\%) \\
\hline Factor 1 \\
\hline $\begin{array}{l}\text { I know how to select suitable } \\
\text { social networks in order to carry } \\
\text { out the learning activities }\end{array}$ \\
\hline $\begin{array}{l}\text { I know how to select suitable } \\
\text { websites in order to carry out the } \\
\text { learning activities }\end{array}$ \\
\hline $\begin{array}{l}\text { I know how to select relevant } \\
\text { information in order to carry out } \\
\text { the learning activities }\end{array}$ \\
\hline
\end{tabular}

\begin{tabular}{ll}
\hline Factor 2 \\
\hline $\begin{array}{l}\text { I know how to distinguish } \\
\text { between valid and non-valid } \\
\text { information in order to carry out } \\
\text { the learning activities }\end{array}$ \\
\hline $\begin{array}{l}\text { I know how to identify reliable } \\
\text { information sources for the lear- } \\
\text { ning activities }\end{array}$ \\
\hline $\begin{array}{l}\text { I know how to discard the infor- } \\
\text { mation I do not need in order to } \\
\text { carry out the learning activities }\end{array}$ \\
\hline $\begin{array}{l}\text { I know how to surf the net } \\
\text { without losing sight of my }\end{array}$ \\
initial objective for the learning \\
activities \\
\hline $\begin{array}{l}\text { I know how to judge the quality } \\
\text { of the information I find in order } \\
\text { to carry out the learning activities }\end{array}$ \\
\hline Factor 3 \\
\hline I know how to select what I want \\
to have in my digital folder
\end{tabular}


Furthermore, the students indicate the extent to which the following e-portfolio functions have contributed to the development of each competency (nothing, a little, quite a lot, a great deal): 1 . Academic tasks; 2. Internet resources; 3 . Dialogue with the teacher; 4. Teacher's portfolio; 5 . Schedule; 6 . Guest resource.

For the purpose of achieving the third objective of the study, information was gathered on the following variables:

- Study habits: scale of five items with answer options from 1 to 5 indicating the frequency of each study habit (from never to always) selected from the perspective of the processes of self-regulated learning:

(1) I study on my own

(2) I study in a group

(3) I only use class notes for studying

(4) I use all the materials provided by the teacher for studying

(5) I use resources that I find myself online for studying

- Attitude towards reflection: : scale of six items with answer options from 1 to 5 indicating the frequency of each reflection attitude (from never to always) selected from the perspective of the processes of self-regulated learning:

(1) I try to argue my ideas clearly so that they are easily understood by those who read them

(2) I like to be made aware of the aspects that I need to improve

(3) I am interested in comparing my learning products with the learning objectives

(4) I like to reflect on my learning

(5) When I am asked to reflect, I understand what is being asked of me

(6) I feel satisfied with the reflective activity I carry out

- Teacher's role in raising awareness about the use of the e-portfolio: scaled question for students with five response levels: none, a little, sometimes, quite a lot and a great deal.

- Didactic treatment in the use of the e-portfolio: one part of the sample has employed the e-portfolio in a year-long work placement subject $(\mathrm{N}=28)$ while the other part of the sample has employed the e-portfolio in semester-long theory and practice subjects $(\mathrm{N}=33)$.

Students' performance: measured by means of the grade achieved in the subject in which the e-portfolio is employed.

\subsection{Sample}

The sample was composed of 61 students who, during the 2014 academic year, had used the e-portfolio-PLE in one of their subjects. Specifically, it was made up of students from three university courses: the Degree in Early Childhood Education of the University of Vic (19.7\%), the Degree in Social Education of the University of Vic (34.4\%) and the Master's Degree in Legal Practice of the University of Barcelona (45.9\%). The mean (M) age of the students was 24 years old and they were mostly female $(65.2 \%)$. In relation to the teaching staff, we highlight the characteristics listed in the table below (Table 3):
Table 3. Characteristics of teaching staff

\begin{tabular}{lllll}
\hline Teachers & Sex & $\begin{array}{c}\text { Teaching } \\
\text { experience }\end{array}$ & Courses & $\begin{array}{c}\text { Experience } \\
\text { in e-port- } \\
\text { folios }\end{array}$ \\
\hline 1 & Female & $\begin{array}{l}\text { Junior (less } \\
\text { than 10 } \\
\text { years) }\end{array}$ & $\begin{array}{l}\text { Early } \\
\text { Childhood } \\
\text { Education }\end{array}$ & $\begin{array}{l}\text { Yes (more } \\
\text { than five } \\
\text { years) }\end{array}$ \\
\cline { 3 - 4 } & & $\begin{array}{l}\text { Social } \\
\text { Education }\end{array}$ & \\
\hline 2 & Male & $\begin{array}{l}\text { Senior } \\
\text { (more than } \\
\text { 20 years) }\end{array}$ & Legal & $\begin{array}{l}\text { Yes (more } \\
\text { than five } \\
\text { years) }\end{array}$ \\
\hline
\end{tabular}

Some of the characteristics that define the university contexts of the sample are as follows: the University of Vic is private and has 5,000 enrolled students, while the University of Barcelona is public and has 46,000 enrolled students. These two universities were selected by means of a convenience sample since, thanks to its teaching work in these universities, the research team had easy access to the sample. Furthermore, it reflects two types of scenario: a small, private university and a large, public one

\section{RESULTS}

\subsection{Students' own perception of the development of the planning, reflection and information selection competences with the use of the e-portfolio}

The students have a positive perception of the potential offered by the e-portfolio for the development of competences. On a scale of 1 to 5 (where 3 is the midpoint), the mean score obtained in the Planning competence is $3.2(\mathrm{~N}=61$, standard deviation $(\mathrm{SD})=$ $0,40)$, the mean score obtained in the Reflection competency is 3.5 $(\mathrm{N}=61, \mathrm{~S}=0.42)$ and the mean score obtained in the Information selection competency is $3.5(\mathrm{~N}=61, \mathrm{~S}=0.39)$. These results indicate that the development of the three competences is perceived in a similar way (although with a slightly lower score in the case of planning) and that they are developed to a moderately greater extent than before using the e-portfolio.

A detailed study of each indicator shows that in the case of the Planning competency (Table 2), the aspects that students consider to be most strengthened through the use of the e-portfolio are those related to the coordination of the programme of the subject with educational objectives. These are the items highlighted in bold in the table below (Table 4).

Table 4. Descriptive statistics of the Planning scale

\begin{tabular}{lcc}
\hline \multicolumn{1}{c}{ Planning of learning } & M & SD \\
\hline $\begin{array}{l}\text { I keep the teaching programme in mind throughout } \\
\text { the subject }\end{array}$ & 3.28 & .985 \\
\hline $\begin{array}{l}\text { I plan in a diary the dates for carrying out the activi- } \\
\text { ties of the subject }\end{array}$ & 3.11 & .915 \\
\hline $\begin{array}{l}\text { I make lists of what I need to have or know in order to } \\
\text { carry out the activities }\end{array}$ & 3.16 & .757 \\
\hline I know how to manage my study time & 3.00 & .753 \\
\hline I need the teacher & 2.95 & .825 \\
\hline $\begin{array}{l}\text { to plan my study time and the completion dates of } \\
\text { activities }\end{array}$ & 3.38 & .840 \\
\hline I submit assignments by the indicated due date & 3.34 & .655 \\
\hline
\end{tabular}




\begin{tabular}{lrr}
\hline $\begin{array}{l}\text { I am concerned to know how each of the studied } \\
\text { topics will help me in my future career }\end{array}$ & 3.38 & .553 \\
\hline $\begin{array}{l}\text { I plan in order to work out how to achieve the compe- } \\
\text { tences I need for the subject }\end{array}$ & 3.10 & .724 \\
\hline $\begin{array}{l}\text { I draw up personal goals geared toward completing } \\
\text { courses and other activities in order to achieve certain }\end{array}$ & 2.89 & 1.0 \\
competences & & 18 \\
\hline
\end{tabular}

I plan subjects well

In the Reflection competency, the aspects that improve after the use of the e-portfolio are those related to the actions of the reflection (Table 3): reflecting on achievements, difficulties and strategies for improvement, specifically, the items highlighted in bold in the table below (Table 5).

Table 5. Descriptive statistics of the Reflection scaleç

\begin{tabular}{lcc}
\hline \multicolumn{1}{c}{ Reflection on learning } & M & SD \\
\hline $\begin{array}{l}\text { I reflect at the start of the subject on the learning that } \\
\text { I must carry out }\end{array}$ & 3.48 & .648 \\
\hline $\begin{array}{l}\text { I reflect at the end of the subject on the learning } \\
\text { achieved }\end{array}$ & 3.77 & .693 \\
\hline $\begin{array}{l}\text { I reflect in each activity on the learning achieved } \\
\text { through it }\end{array}$ & 3.69 & .827 \\
\hline $\begin{array}{l}\text { I reflect on the competences that help to achieve the } \\
\text { learning activities }\end{array}$ & 3.41 & .783 \\
\hline I only think about how to pass the subjects & 2.80 & .963 \\
\hline I reflect even when not asked to do so by the teacher & 3.57 & .741 \\
\hline My reflection is of a self-critical nature & 3.48 & .673 \\
\hline My reflection is of a constructive nature & 3.57 & .670 \\
\hline I am aware of the usefulness of reflection & 3.54 & .721 \\
\hline I take the time necessary to reflect & 3.33 & .870 \\
\hline
\end{tabular}

Last of all, in the Information selection competency, we observe that the most strengthened aspects are the search for information and the selection of learning evidence (Table 4). Specifically, , they are the items highlighted in bold in the table below (Table 6).

Table 6. Descriptive statistics of the Information selection scale

\begin{tabular}{lcc}
\hline \multicolumn{1}{c}{ Information selection } & M & SD \\
\hline $\begin{array}{l}\text { I know how to select suitable websites in order to } \\
\text { carry out the learning activities }\end{array}$ & 3.48 & .622 \\
\hline $\begin{array}{l}\text { I know how to select suitable social networks in order } \\
\text { to carry out the learning activities }\end{array}$ & 3.48 & .566 \\
\hline $\begin{array}{l}\text { I know how to select relevant information in order to } \\
\text { carry out the learning activities }\end{array}$ & 3.56 & .563 \\
\hline $\begin{array}{l}\text { I know how to distinguish between valid and non-va- } \\
\text { lid information in order to carry out the learning } \\
\text { activities }\end{array}$ & 3.46 & .565 \\
\hline $\begin{array}{l}\text { I know how to judge the quality of the information I } \\
\text { find in order to carry out the learning activities }\end{array}$ & 3.44 & .592 \\
\hline $\begin{array}{l}\text { I know how to discard the information I do not need } \\
\text { in order to carry out the learning activities }\end{array}$ & 3.38 & .522 \\
\hline $\begin{array}{l}\text { I know how to surf the net without losing sight of my } \\
\text { initial objective for the learning activities }\end{array}$ & 3.46 & .565 \\
\hline $\begin{array}{l}\text { I know how to identify reliable information sources } \\
\text { for the learning activities }\end{array}$ & 3.38 & .610 \\
\hline
\end{tabular}

\begin{tabular}{llll}
\hline $\begin{array}{l}\text { I know how to select what I have to show in the } \\
\text { learning activities }\end{array}$ & 3.48 & .536 \\
\hline $\begin{array}{l}\text { I know how to select what I want to have in my dig- } \\
\text { ital folder }\end{array}$ & 3.64 & .775 \\
\end{tabular}

In the correlation tests, as shown in table 7, there is a positive and significant correlation between the Planning, Selection and Reflection competences in terms of their development, in such a way that when the students consider that one of the competences has improved, they feel the same way about the other competences.

Table 7. Correlations (Pearson) between the development of the competences

\begin{tabular}{|c|c|c|c|}
\hline & Planning & Reflection & Selection \\
\hline \multirow[b]{2}{*}{ Planning } & \multirow[b]{2}{*}{1} & $0.558 * *$ & $0.575^{* *}$ \\
\hline & & $\begin{array}{r}(\mathrm{p}=0.000 \\
\mathrm{N}=61)\end{array}$ & $\begin{array}{r}(\mathrm{p}=0.000, \\
\mathrm{N}=61)\end{array}$ \\
\hline \multirow[b]{2}{*}{ Reflection } & & \multirow[b]{2}{*}{1} & $0.657^{* *}$ \\
\hline & & & $\begin{array}{r}(\mathrm{p}=0.000, \\
\mathrm{N}=61)\end{array}$ \\
\hline Selection & & & 1 \\
\hline
\end{tabular}

** The correlation is significant at the level of 0.01 (bilateral)

\subsection{Finding out the students' perception of the degree to which each function of the e-portfolio helps in the development of the three competences.}

Concerning the use of the e-portfolio for each of the competences, the students consider that the most helpful functions in general for all the competences are: the Schedule, the Academic tasks, the Teacher's portfolio and Dialogue with the teacher, as can be observed in Figure 1.

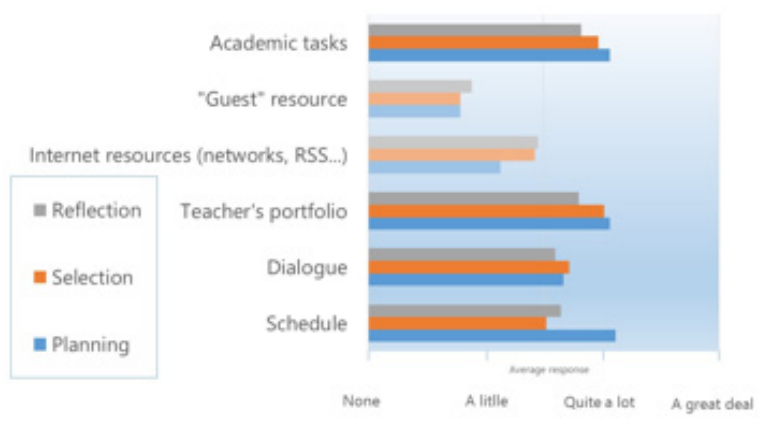

Figure 1. Use of the resources of the e-portfolio for each competency

\subsection{Verifying the possible influence of variables related to the perception of the development of competences}

a) As far as study habits are concerned, the students are more focused on individual work (as opposed to group work) and on the work of the subjects whose materials, such as books, articles, presentations, etc. are provided by the teacher (as opposed to 
working solely with their class notes or with resources they find on the Internet).

It has been shown that the perception of the development of the competences does not correlate with study habits, with the exception of Planning, which does correlate positively with the fact of working on the subject with all the materials provided by the teacher $(\mathrm{r}=0.332, \mathrm{p}=0.009, \mathrm{~N}=61)$.

b) The participants, on average, start from a positive attitude towards reflection, obtaining a mean score of 3.34 (on a scale of 1 to $5, \mathrm{~N}=61, \mathrm{~S}=0.39$ ).

As shown in Table 8, none of the three competences correlates significantly with the attitude towards reflection.

Table 8. Correlation (Pearson) of the development of competences with the attitude towards reflection

\begin{tabular}{ll}
\hline \multicolumn{1}{c}{ Competency } & \multicolumn{1}{c}{$\begin{array}{c}\text { Correlation with } \\
\text { Attitude towards reflection }\end{array}$} \\
\hline Planning & $0.151(\mathrm{p}=0.245, \mathrm{~N}=61)$ \\
\hline Reflection & $0.239(\mathrm{p}=0.064, \mathrm{~N}=61)$ \\
\hline Selection & $0.166(\mathrm{p}=0.200, \mathrm{~N}=61)$ \\
\hline
\end{tabular}

c) The extent to which the teacher has raised awareness about the use of the e-portfolio has obtained a mean score of 4.2 (on a scale of 1 to $5, \mathrm{~N}=43, \mathrm{~S}=1.00$ ). This variable has not shown significant correlation with any of the analysed competences (see Table 9).

Table 9. Correlation (Pearson) of the development of the competences with the degree to which the teacher has raised awareness about the use of the e-portfolio

\begin{tabular}{ll}
\hline Competency & \multicolumn{1}{c}{$\begin{array}{c}\text { Correlation with } \\
\text { Degree of awareness of the } \\
\text { teacher }\end{array}$} \\
\hline Planning & $0.227(\mathrm{p}=0.143, \mathrm{~N}=43)$ \\
\hline Reflection & $-0.078(\mathrm{p}=0.617, \mathrm{~N}=43)$ \\
\hline Selection & $0.126(\mathrm{p}=0.423, \mathrm{~N}=43)$ \\
\hline
\end{tabular}

d) Significant differences have been found in respect of the type of subject in the Reflection competency $(\mathrm{t}=2.494, \mathrm{gl}=59$, $\mathrm{p}=0.015)$, in such a way that the students of the year-long work placement subject reflect "more than before the use of the Digital Folder platform" than the students of the semester-long theory and practice subjects (Table 10).

Table 10. Descriptive statistics of the perception of development for each competency according to the type of subject

\begin{tabular}{lllll}
\hline Competency & \multicolumn{1}{c}{ Type of subject } & N & M & SD \\
\hline \multirow{2}{*}{ Planning } & $\begin{array}{l}\text { Theory-practice }- \\
\text { Semester }\end{array}$ & 33 & 3.16 & 0.05 \\
\cline { 2 - 5 } & $\begin{array}{l}\text { Work placement - } \\
\text { Full year }\end{array}$ & 28 & 3.16 & 0.09 \\
\hline \multirow{2}{*}{ Reflexión } & $\begin{array}{l}\text { Theory-practice - } \\
\text { Semester }\end{array}$ & 33 & 3.35 & 0.07 \\
\cline { 2 - 5 } & $\begin{array}{l}\text { Work placement - } \\
\text { Full year }\end{array}$ & 28 & 3.60 & 0.08 \\
\hline Selección & $\begin{array}{l}\text { Theory-practice }- \\
\text { Semester-long }\end{array}$ & 33 & 3.44 & 0.06 \\
\hline
\end{tabular}

\begin{tabular}{llll}
\hline $\begin{array}{l}\text { Work placement }- \\
\text { Year-long }\end{array}$ & 28 & 3.52 & 0.08 \\
\hline
\end{tabular}

e) As regards to the relationship between performance (grade) and the analysed competences, no statistically significant correlation has been found (see Table 11).

Table 11. Correlation (Pearson) of the development of competences with the grade

\begin{tabular}{lc}
\hline Competency & \multicolumn{1}{c}{$\begin{array}{c}\text { Correlation with } \\
\text { Grade }\end{array}$} \\
\hline Planning & $-0.112(\mathrm{p}=0.480, \mathrm{~N}=42)$ \\
\hline Reflection & $-0.031(\mathrm{p}=0.846, \mathrm{~N}=42)$ \\
\hline Selection & $-0.268(\mathrm{p}=0.086, \mathrm{~N}=42)$ \\
\hline
\end{tabular}

\section{DISCUSSION}

In line with the model of personal organisation (Johnson \& Liber, 2008), we consider that, according to the students' perception, the learning activities have been connected to higher-level cognitive functions related to planning to a greater extent than before the use of the e-portfolio.

Furthermore, the improvement in the perception of the reflection competency leads us to draw the conclusion that the self-delivery functions (such as the schedule and dialogue with the teacher) have been managed in a balanced way with the self-development functions (use of the functions of the e-portfolio for the learning itself).

The study results, related to the development of cross-cutting competences of a metacognitive nature, in this case planning, reflection and information selection, are in line with the results of previous research (Logar, Peterson, \& Römmer-Nossek, 2007; Meyer et al., 2010; Plaisir, Hachey \& Theilheimer, 2011).

The reflection competency has seen the greatest development in aspects such as autonomy ("I reflect even when not asked to do so by the teacher") and improvement ("My reflection is of a constructive nature"). The autonomy shown in this case is in line with the result found with respect to the absence of a relationship between the degree to which the teacher has raised the students' awareness about the personal use of the e-portfolio and the development of cross-cutting competences.

The development of reflection has also been strengthened by the constant application of this competency ("I reflect in each activity on the learning achieved through it"), which enables deeper learning since the variations in points of view can become known while the actions are being carried out (Hole \& McEntee, 1999; Riedinger, 2006). This is coherent with the result found in respect of a greater perception of development in the year-long subject than in the semester-long one.

It is notable that the perception of the development of the reflection competency is not related to the attitude towards reflection. One possible explanation for this is that the predisposition towards reflection does not determine the degree to which the students apply this competency in the e-portfolio.

Last of all, we have observed that the development perceived in respect of cross-cutting competences has not been directly reflected in the grades obtained. This highlights the need for further research in order to find out to what extent cross-cutting competences are assessed, and therefore valued, in subjects.

Overall, the use of a dedicated portfolio environment, with an integrated PLE subcomponent, along with the didactic treat- 
ment used in several subjects, clearly indicate a substantial improvement in the students' perception of how certain technical-pedagogical configurations help them and improve some key competences.

The study is part of the new and necessary trend of research into the PLE. Furthermore, many authors and research projects point towards a study of the kinds of tools that students use and need for their PLE (with professional and academics proposals) and how they have a metacognitive and guided process of appropriation. The study shows how an academic tool can be useful for that purpose. The tool designed is a hybrid of ePortfolio and PLE to elaborate and share the learning process with the learning community,, fostering the development of learning skills.

\section{ACKNOWLEDGEMENTS}

Our acknowledgements are for the Ministerio de Economía y Competitividad (Government of Spain) that finance this project and for the team of research that have been possible the implementation of the experience and the collection of data.

\section{REFERENCES}

Cambridge, D. (2010). Eportfolios for lifelong learning and assessment. San Francisco: Jossey-Bass.

Castañeda, L., \& Adell, J. (Eds.) (2013). Entornos Personales de Aprendizaje: claves para el ecosistema educativo en red. Alcoy: Marfil.

Castañeda, L., Dabbagh, N., \& Torres-Kompen, R. (2017). Personal Learning Environments: Research-Based Practices, Frameworks and Challenges. Journal of New Approaches in Educational Research, 6(1), 1-2. doi:10.7821/naer.2017.1.229

Geyer, P. D., \& Daly, J. P. (1998). Predicting job satisfaction for relocated workers: Interaction of Relocation Consequences and Employee Age. The Journal of Psychology, 132(4), 417-426. doi:10.1080/00223989809599276

Hole, S., \& McEntee, G. H. (1999). Reflection is at the heart of practice. Educational Leadership, 56(8), 34-37.

Johnson, M., \& Liber, O. (2008). The Personal Learning Environment and the human condition: from theory to teaching practice. Interactive Learning Environments, 16(1), 3-15. doi:10.1080/10494820701772652

Justicia, F. (1996). Metacognición y currículum. In J. Beltrán, \& C. Genovard (Eds.), Psicología de la instrucción I. Variables y procesos básicos (pp. 359-381). Madrid: Síntesis.

Kühn, C. (2017). Are students ready to (re)-Design their Personal Learning Environment? The case of the e-Dynamic.Space. Journal of New Approaches in Educational Research, 6(1), 11-19. doi:10.7821/naer.2017.1.185

Littrell, J. M., Malia, J. A., \& Vanderwood, M. (1995). Single-session brief counseling in a High School. Journal of Counseling \& Development, 72, 451-458. doi:10.1002/j.1556-6676.1995.tb01779.x

Logar, S., Peterson, B., \& Roemmer-Nossek, B. (2007). Media Competences for Tutors - a Modularised Course Using Eportfolio. Using Eportfolio To Integrate A Modularised Course. In Proceedings of Eportfolio 2007. Maastricht.

Meyer, E., Abrami, P. C., Wade, A., Aslan, O., \& Deault, L. (2010). Improving literacy and metacognition with electronic portfolios: Teaching and learning with ePEARL. Computers \& Education, 55(1), 84-91. doi:10.1016/j. compedu.2009.12.005 Wolters, C. (2003). Understanding procrastination from a self-regulated learning perspective. Journal of Educational Psychology, 95, 179-187. doi:10.1037/0022-0663.95.1.179

Nunnally, J. C., \& Bernstein, I. J. (1995). Teoría psicométrica. México: McGraw Hill.

Pintrich, P. (2004). A conceptual framework for assessing motivation and self-regulated learning in college students". Educational Psychology Review, 16(4), 385407. doi:10.1007/s10648-004-0006-X

Plaisir, J. Y., Hachey, A. C., \& Theilheimer, R. (2011). Their portfolios, our role: Examining a community college teacher education digital portfolio program from the students' perspective. Journal of Early Childhood Teacher Education, 32(2), 159-175. doi:10.1080/10901027.2011.572231

Riedinger, B. (2006). Mining for meaning: Teaching students how to reflect. In A. Jafari, \& C. Kaufman (Eds.), Handbook of research on eportfolios (pp. 90-101). Hershey PA: Idea Group Reference. doi:10.4018/978-1-59140-890-1.ch010

Rodríguez, J.L.; Galván, C.; Martínez, F. (2013). El portafolios digital como herramienta para el desarrollo de competencias transversales en el alumnado. TESI. Teoría de la Educación. Educación y Cultura en la Sociedad de la Información, 14(2), 157-177.
Rodríguez-Illera, J. L., Rubio, M. J., Galván, C., \& Barberà, E. (2014). Diseño de un entorno mixto e-portfolio/PLE centrado en el desarrollo de competencias transversales. EDUTEC, Revista Electrónica de Tecnología Educativa, 47. Retrieved from http://edutec.rediris.es/Revelec2/Revelec47/n47_Rodriguez-Rubio-Galvan-Barbera.html

Rosario, P., Núñez, J., \& González-Pineda, J. (2006). Comprometer-se como estudar na Universidade: Cartas do Gervásio ao seu Umbigo. Coimbra: Almedina.

Siemens, G. (May 13, 2007). Personal learning environments [Blog post]. Retrieved from http://www.elearnspace.org/blog/2007/05/13/personal-learning-environments-6/

Torrano, F., \& González, M. (2004). Self-Regulated learning: Current and Futures Directions. Electronic Journal of Research in Educational Psychology, 2(1), 1-34.

Torres-Kompen, R., Buchem, R., \& Attwell, G. (2011). Understanding Personal Learning Environments: Literature Review and synthesis through Activity theory lens. Learning, 54(2), 1-33.

Villa, A., \& Poblete, M. (2007). Aprendizaje basado en competencias. Bilbao: Mensajero.

Wilson, T.D. (1999). Models in information behaviour research. Journal of Documentation, 55(3), 249-270.

Zimmerman, B. (2002). Becoming Learner: Self-Regulated Overview. Theory into Practice, 41, 64-70.

Zubizarreta, J. (2004; 2009). The learning portfolio. San Francisco: Anker.

How to cite this article: Galván, C., Rubio, M. J., Martínez, F., \&

Rodríguez, J. L. (2017). Can the integration of a PLE in an e-portfolio platform improve generic competences? Journal of New Approaches in Educational Research, 6(2), 112-118. doi: 10.7821/naer.2017.7.230 